\title{
Snapshot of COVID-19 Related Clinical Trials in India
}

\author{
Jaykaran Charan ${ }^{1}$ (D) Rimplejeet Kaur ${ }^{2}$ Pankaj Bhardwaj ${ }^{3}$ Tanuj Kanchan ${ }^{4}$.

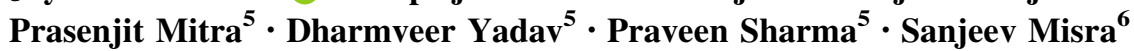

Received: 18 July 2020/Accepted: 4 August 2020/Published online: 10 August 2020

(C) Association of Clinical Biochemists of India 2020

\begin{abstract}
Many interventions are being explored for the prophylaxis and treatment of COVID-19 in all over the world including India. There was a need of systematic data about the COVID-19 related clinical trials conducted in India. The aim of the present study was to analyze various clinical trials registered in Clinical Trial Registry of India (CTRI) exploring the interventions for COVID 19. The data of various clinical trials being conducted in India was obtained from CTRI. Different trial characteristics were extracted in the predesigned proforma and analyzed. Values were expressed in frequency and percentages. As of 11th July, 2020, a total of 203 trials were registered in the CTRI. The majority of the trials $(61 \%)$ were related to the AYUSH interventions. Only 3 trials were international while the others were national. A major portion of public and private funding were dedicated to the AYUSH trials. More number of trials were for treatment as compared to prophylaxis. Maharashtra and Delhi are having highest number of trial sites. There is a good progress regarding
\end{abstract}

Jaykaran Charan

dr.jaykaran78@gmail.com

1 Department of Pharmacology, All India Institute of Medical Sciences, Jodhpur, India

2 Department of Pharmacology, S.N. Medical College, Jodhpur, India

3 Department of Community and Family Medicine, All India Institute of Medical Sciences, Jodhpur, India

4 Department of Forensic Medicine, All India Institute of Medical Sciences, Jodhpur, India

5 Department of Biochemistry, All India Institute of Medical Sciences, Jodhpur, India

6 Department of Surgical Oncology, All India Institute of Medical Sciences, Jodhpur, India
AYUSH clinical trials, and a similar progress is expected for allopathic interventions.

Keywords COVID 19 . Trials · AYUSH - Treatment . Prophylaxis

\section{Introduction}

COVID-19 is a pandemic that emerged in the majority of the countries after its origin in Wuhan, China. India is amongst the countries having a high number of cases and looking at the current trend; it could be soon in the top spot in terms of cases [1,2]. Observing the morbidity and mortality associated with COVID-19, it is going to have a long-lasting effect on the people, policymakers, doctors etc. As happened in most of the emerging diseases, there is no treatment or prevention modality available which is based on the principle of evidence based medicine (EBM). In view of this, lot of research is happening all over the world to generate evidences for new treatment modalities and diagnostics for COVID19. There were around 60 COVID-19 related clinical trials in January 2020 which increased to around 4000 in first week of July [3]. A number of significant and important trials have already done interim analysis, and whose reports are already published or is in process of being published. This is expected to have a positive impact in the COVID-19 related patient care [4-6]. Currently the entire world is in dire need of vaccines which seems to be the only solution for preventing second wave of the infection and developing herd immunity [7]. So, in present times, it is expected that scientists, researchers and clinicians should involve themselves in the clinical and basic research to find treatment and diagnostic modalities against this disease. ICMR 
Table 1 Characteristics of COVID 19 related trails registered in CTRI

\begin{tabular}{|c|c|c|c|}
\hline Parameter & Frequency & Parameter & Frequency \\
\hline Type of intervention & $(\mathrm{N}=203)$ & Sponsor type & $(\mathrm{N}=203)$ \\
\hline Allopathic & $64(31.53)$ & Public & $(\mathrm{N}=104)$ \\
\hline AYUSH & $125(61.58)$ & Allopathic & $25(24.04)$ \\
\hline Nutraceutical & $7(3.45)$ & AYUSH & $73(70.19)$ \\
\hline Process of care changes & $4(1.97)$ & Nutraceutical & $1(0.96)$ \\
\hline Radiation therapy & $1(0.49)$ & Process of care changes & $3(2.88)$ \\
\hline Surgical/anesthesia & $2(0.99)$ & Surgical/anesthesia & $2(1.92)$ \\
\hline AYUSH intervention type & $(\mathrm{N}=125)$ & Private & $(\mathrm{N}=99)$ \\
\hline Ayurvedic & $87(69.60)$ & Allopathic & $39(39.80)$ \\
\hline Yoga and Naturopathy & $4(3.20)$ & AYUSH & $52(53.06)$ \\
\hline Unani & $5(4.00)$ & Nutraceutical & $6(6.12)$ \\
\hline Siddha & $14(11.20)$ & Process of care changes & $1(1.02)$ \\
\hline Homeopathy & $15(12.00)$ & Surgical/anesthesia & $0(0.0)$ \\
\hline Location of trial site & $(\mathrm{N}=203)$ & Radiation Therapy & $0(0.0)$ \\
\hline India & $200(98.5)$ & Not mentioned & $1(1.02)$ \\
\hline Global & $3(1.5)$ & Phase of trial & $(\mathrm{N}=203)$ \\
\hline Number of centres & $(\mathrm{N}=203)$ & Phase 1 & $3(1.48)$ \\
\hline Single & $159(78.33)$ & Phase 2 & $57(28.08)$ \\
\hline Multicentric & 44 (21.67) & Phase 3 & $37(18.23)$ \\
\hline Purpose of trial & $(\mathrm{N}=203)$ & Phase 4 & $4(1.97)$ \\
\hline Treatment & $134(66.01)$ & Phase $1 \& 2$ & $7(3.45)$ \\
\hline Prophylaxis & $67(33.00)$ & Phase $2 \& 3$ & $24(11.82)$ \\
\hline Screening & $2(0.99)$ & Phase $3 \& 4$ & $12(5.91)$ \\
\hline Duration of study & $(\mathrm{N}=203)$ & Post marketing surveillance & $3(1.48)$ \\
\hline Less than 1 month & $5(2.46)$ & NA & $56(27.59)$ \\
\hline $1-3$ months & $28(13.79)$ & Publication status & $(\mathrm{N}=203)$ \\
\hline $3-6$ months & $64(31.79)$ & Not mentioned & $20(9.85)$ \\
\hline 6 months to 1 year & $70(34.48)$ & Not yet published & $180(88.67)$ \\
\hline 1 year and above & $34(16.75)$ & Sent for publication & $1(0.49)$ \\
\hline Not mentioned & $2(0.99)$ & Published & $2(0.99)$ \\
\hline
\end{tabular}

National Task Force for COVID-19 constituted groups related to clinical research, research on diagnostic and biomarkers, epidemiology and surveillance, operational research, vaccine and drug research to set up the research priorities for COVID-19 in India [8]. With these efforts at the government level, it is expected that high-quality research should be undertaken in India and the synthesized results should be available to give further guidance. India is amongst the top 10 countries in terms of the research publications generated for COVID-19 but no systematic analysis of the registered clinical trials is available [3]. Availability of such information is required for the better understanding of this not only researchers and academicians but also to policy makers and government. With this objective, we have designed this study to explore the Clinical Trial Registry of India (CTRI) data to see what kind of clinical trials are being conducted for COVID 19 in India. This will give us a snapshot of the current situation and will provide us with a information regarding potential interventions for COVID 19 from India.

\section{Methods}

This study was based on data available in the public domain. For this study, the data was collected from the CTRI, which is an operated by the National Institute of Medical Statistics, Indian Council of Medical Research [9]. Data for the analysis was compiled on 11th July 2020. Data of COVID-19 related trials was searched by using different keywords. The data was cleaned, and any discrepancy related to classification, funding etc. was resolved by mutual consensus between first and second author [JC, $\mathrm{RK}$ ]. Observational studies registered in the CTRI were excluded from the analysis. So, data includes all the COVID 19 related clinical trials being conducted in India 
Table 2 COVID 19 related allopathic interventions in CTRI registered trials

\begin{tabular}{|c|c|c|}
\hline $\begin{array}{l}\text { S. } \\
\text { no. }\end{array}$ & Allopathic intervention $(\mathrm{N}=64)$ & $\begin{array}{l}\text { Frequency } \\
(\%)\end{array}$ \\
\hline 1 & Acalabrutinib & $1(1.56)$ \\
\hline 2 & BCG vaccine & $4(6.25)$ \\
\hline 3 & Convalescent plasma & $10(15.63)$ \\
\hline 4 & Antiphospholipid antibody (APLA) & $1(1.56)$ \\
\hline 5 & Chloroquine & $3(4.69)$ \\
\hline 6 & Cytokine cocktail therapy & $1(4.69)$ \\
\hline 7 & 2-Deoxy-D-Glucose & $1(1.56)$ \\
\hline 8 & $\mathrm{C} 21$ & $1(1.56)$ \\
\hline 9 & $\begin{array}{l}\text { Combination of nitazoxanide and } \\
\text { hydroxychloroquine }\end{array}$ & $1(1.56)$ \\
\hline 10 & $\begin{array}{l}\text { Resveratrol-copper and sodium-copper- } \\
\text { chlorophyllin }\end{array}$ & $2(3.13)$ \\
\hline 11 & Favipavir & $2(3.13)$ \\
\hline 12 & Hydroxychloroquine & $5(7.81)$ \\
\hline 13 & $\begin{array}{l}\text { Hydroxychloroquine, ribavirin, ST-NS; } \\
\text { hydroxychloroquine, ribavirin, ST-S; } \\
\text { lopinavir, ritonavir, ribavirin, ST-S }\end{array}$ & $1(1.56)$ \\
\hline 14 & Hydroxychloroquine, ciclesonide, ivermectin & $1(1.56)$ \\
\hline 15 & Hydroxychloroquine and azithromycin & $1(1.56)$ \\
\hline 16 & IFN alfa-2b & $1(1.56)$ \\
\hline 17 & Imatinib & $1(1.56)$ \\
\hline 18 & Inj Sepsivac & $1(1.56)$ \\
\hline 19 & Immunoglobulin therapy & $1(1.56)$ \\
\hline 20 & Itolizumab & $1(1.56)$ \\
\hline 21 & Ivermectin & $6(9.38)$ \\
\hline 22 & Lithium & $1(1.56)$ \\
\hline 23 & Mycobacterium w & $3(4.69)$ \\
\hline 24 & $N$-Acetylcysteine & $1(1.56)$ \\
\hline 25 & Nafamostat mesilate & $1(1.56)$ \\
\hline 26 & Niclosamide & $1(1.56)$ \\
\hline 27 & Ozone therapy & $1(1.56)$ \\
\hline 28 & Povidone iodine gargle & $1(1.56)$ \\
\hline 29 & Sofosbuvir & $1(1.56)$ \\
\hline 30 & Tocilizumab & $1(1.56)$ \\
\hline 31 & Lignocaine & $1(1.56)$ \\
\hline 32 & Topical povidone iodine & $1(1.56)$ \\
\hline 33 & Ulinastatin & $1(1.56)$ \\
\hline 34 & Ultraviolet $\mathrm{C}$ therapy & $1(1.56)$ \\
\hline 35 & Vitamin D3 & $2(3.13)$ \\
\hline 36 & Novel artificial intelligence algorithm & $1(1.56)$ \\
\hline
\end{tabular}

as it is mandatory to register each and every clinical trial in the CTRI. Various trial characteristics (Title, Type of intervention, Location, Phase of trial, sponsoring agency, etc.) were extracted in predesign proforma and doubly checked for accuracy. Data was entered in the Microsoft
Table 3 Frequency of COVID 19 related clinical trials in different states of India

\begin{tabular}{lll}
\hline S. no. & State & Number of trials $(\mathrm{N}=203)$ \\
\hline 1 & Maharashtra & $53(26.11)$ \\
2 & Delhi & $51(25.12)$ \\
3 & Uttar Pradesh & $30(14.78)$ \\
4 & Tamil Nadu & $27(13.30)$ \\
5 & Karnataka & $24(11.82)$ \\
6 & Gujarat & $22(10.84)$ \\
7 & Andhra Pradesh & $17(8.37)$ \\
8 & Rajasthan & $16(7.88)$ \\
9 & Madhya Pradesh & $16(7.88)$ \\
10 & Chhattisgarh & $10(4.93)$ \\
11 & Telangana & $7(3.45)$ \\
12 & Chandigarh & $7(3.45)$ \\
13 & West Bengal & $5(2.46)$ \\
14 & Uttarakhand & $4(1.97)$ \\
15 & Haryana & $3(1.48)$ \\
16 & Puducherry & $2(0.99)$ \\
17 & Bihar & $2(0.99)$ \\
18 & Odisha & $2(0.99)$ \\
19 & Jammu \& Kashmir & $1(0.49)$ \\
20 & Nagaland & $1(0.49)$ \\
21 & Meghalaya & $1(0.49)$ \\
22 & Goa & $1(0.49)$ \\
\hline
\end{tabular}

excel and analysis was done. No inferential statistics were done; and the descriptive statistics were reported in the form of frequency and percentages.

\section{Results}

In total 331 studies were registered in CTRI as of 11th July. Out of these, $203(61.3 \%)$ were trials, and $128(38.7 \%)$ were observational studies. Out of 203 trials, $125(61.5 \%)$ were AYUSH trials, and $64(30.7 \%)$ were allopathic trials. Amongst the AYUSH $(n=125), 87(69.6 \%)$ were trial exploring ayurvedic interventions followed by homeopathy $(12 \%)$ and siddha $(11.2 \%)$. The majority of trials were national, and only $3(1.4 \%)$ were global. Single centre trials were predominant as compared to the multicentric trials (159 vs. 44). Sponsoring was almost equal form public and private sector, and amongst the public funding $(\mathrm{n}=104)$, the significant portion goes to AYUSH trials $73(70.1 \%)$ and same in the case of private funding, where around $50 \%$ trials were AYUSH trials. Majority of the trials were of phase 2 and phase 3 . Around $45 \%$ of trials had a duration of less than 6 months. The majority of the trials were associated with the "treatment" of COVID 19 as compared to the "prophylaxis" 
of COVID 19 (134 vs 67). Leading states where these trials are being conducted are Maharashtra and Delhi. In the case of AYUSH trials, most frequent interventions which were explored in the trials were Arsenicum Album, Ashwagandha, AYUSH-64 and Guduchi Ghan Vati. Twelve trials related to the Chloroquine and Hydroxychloroquine as monotherapy or with other drugs are registered on CTRI. There were ten trials related to the convalescent plasma therapy, 6 trials were related to the Itolizumab and 2 trials were related to the Favipavir (Tables 1, 2, 3).

\section{Discussion}

The majority of the trials are related to ayurvedic drugs or drug combinations. This is a welcome finding. Ayurveda is a traditional medicine system of India which, as per experts, could not be developed as science because of being neglected at various levels [10]. In the current situation where aggressive efforts are needed to find something which may help against COVID 19, drugs from the indigenous system must be explored against the COVID 19. It seems that the Ministry of AYUSH is making reasonable efforts to encourage researchers to explore these products for COVID 19. This is a good sign of future integration between allopathic and AYUSH system, as the practitioners from both streams are working together for the first time. Many ayurvedic preparations like Amalaki (Emblica officinalis), Ashwagandha (Withania somnifera), Guduchi (Tinospora cordifoloia) etc. are known to have immunomodulation properties and all these preparation are being explored in these trials and as these preparations are used since years for many diseases, has proved record of safety [11, 12]. Efforts should also be done to follow the same rigorous method for AYUSH trials as it is followed for allopathic trials and each trial results should be available on CTRI website as well as should be published in peer reviewed journals for wider dissemination. COVID-19 has given us an opportunity to integrate AYUSH with modern evidence based medicine in the form of clinical trials. As such it is believed that Ayurveda drugs are safe drugs but this notion may be challenged once the safety data from these trials are reported and that will be a very good sign for patient care as considering a medicine safe should be based on systematic evidences and not otherwise. There are Around half of the trials are of less than 6-month duration, it means we are going to get results of these trials within few months and this will help us to take a call about the use of these interventions. As per the record, very few trials are global, and the majority of the trials are national. A lot of trials are happening all over the world, and India should be the participant of these trials looking at the number of cases and heterogeneous population of the country [3]. Efforts need to be done at various levels (government, institution, and researcher) to establish communication with the investigators or agencies involved in such trials so that India may also contribute in the fight against the COVID 19 at the global level. There were a good number of trials exploring the effect of chloroquine and hydroxychloroquine. Looking at the current controversy of the use of hydroxychloroquine and conflicting evidences being published in biomedical literature, the publication of these trials will be helpful in establishing or refuting the role of hydroxychloroquine in the treatment of COVID-19 [13].

On the basis of this study it can be concluded that there is a good progress made regarding AYUSH clinical trials however a similar progress is expected for allopathic interventions. A need for international collaboration to initiate multinational allopathic trials needs to be emphasized on.

\section{References}

1. Coronavirus Update (Live): 13,058,762 Cases and 572,001 Deaths from COVID-19 Virus Pandemic-Worldometer [Internet]. Worldometers.info. 2020 [cited 13 July 2020]. https://www. worldometers.info/coronavirus/?utm_campaign= homeAdvegas 1 ?

2. Mitra P, Misra S, Sharma P. COVID-19 pandemic in India: what lies ahead. Ind J Clin Biochem. 2020;35:257-9.

3. Coronavirus research publishing: The rise and rise of COVID-19 clinical trials [Internet]. Natureindex.com. 2020 [cited 18 July 2020]. https://www.natureindex.com/news-blog/the-top-cor onavirus-research-articles-by-metrics.

4. Welcome-RECOVERY Trial: Randomised Evaluation of COVID_19 Therapy [Internet]. Recoverytrial.net. 2020 [cited 18 July 2020]. https://www.recoverytrial.net.

5. Solidarity" clinical trial for COVID-19 treatments [Internet]. Who.int. 2020 [cited 18 July 2020]. https://www.who.int/emer gencies/diseases/novel-coronavirus-2019/global-research-onnovel-coronavirus-2019-ncov/solidarity-clinical-trial-for-covid19-treatments D).

6. Jackson L, Anderson E, Rouphael N, Roberts P, Makhene M, Coler $\mathrm{R}$ et al. An mRNA vaccine against SARS-CoV-2-preliminary report. N Engl J Med. 2020.https://doi.org/10.1056/ NEJMoa2022483

7. Mullard A. COVID-19 vaccine development pipeline gears up. Lancet. 2020;395(10239):1751-2.

8. Icmr.gov.in. 2020 [cited 13 July 2020]. https://www.icmr.gov.in/ pdf/covid/committee/Task_Force.pdf.

9. Clinical Trial Registry of India. ICMR-National Institute of Medical Statistics. http://ctri.nic.in/Clinicaltrials/login.php. Accessed 11 July 2020

10. Bodeker G, Kronenberg F. A public health agenda for traditional, complementary, and alternative medicine. Am J Public Health. 2002;92(10):1582-91.

11. Balasubramani SP, Venkatasubramanian P, Kukkupuni SK, Patwardhan B. Plant-based Rasayana drugs from Ayurveda. Chin J Integr Med. 2011;17(2):88-94. https://doi.org/10.1007/s11655011-0659-5.

12. Agarwal R, Diwanay S, Patki P, Patwardhan B. Studies on immunomodulatory activity of Withania somnifera 
(Ashwagandha) extracts in experimental immune inflammation. J Ethnopharmacol. 1999;67:27-35.

13. Hydroxychloroquine and lopinavir/ritonavir treatment arms for COVID-19 [Internet]. Who.int. 2020 [cited 13 July 2020]. https:// www.who.int/news-room/detail/04-07-2020-who-discontinues- hydroxychloroquine-and-lopinavir-ritonavir-treatment-arms-forcovid-19.

Publisher's Note Springer Nature remains neutral with regard to jurisdictional claims in published maps and institutional affiliations. 